\title{
Hasarı Gerçekçi Şekilde Simüle Eden Dolu Yapımı
}

\author{
Mehmet E. UZ ${ }^{*}$, Gökalp YILMAZ ${ }^{2}$, Talha BIRCAN ${ }^{2}$ \\ ${ }^{1}$ Department of Civil Engineering, Adnan Menderes University, Aydin, 09100, TURKEY \\ and Honorary Research Fellow, School of Civil, Mining and Environmental Engineering, University of \\ Wollongong, Wollongong, NSW 2500, Australia \\ 2 Department of Mechanical Engineering, University of Adnan Menderes, Aydın, Merkez Kampus 09100
}

\begin{tabular}{|c|c|}
\hline Anahtar Kelimeler & Öz \\
\hline $\begin{array}{l}\text { Yapay dolu tanesi, } \\
\text { Soğuk çekilmiş çelik, } \\
\text { Polivinil Alkol fiber, } \\
\text { Polivinil Alkol adhezif, } \\
\text { Pnömatik basınç silahı, } \\
\text { Gerçekçi dolu hasarı, }\end{array}$ & $\begin{array}{l}\text { Dolu firtınalarının sebep olduğu düşünülen hasarın miktarı, deprem ve rüzgar } \\
\text { hasarına eşit olabilmektedir fakat can kaybı ihtimalinin fazla olmaması sebebiyle } \\
\text { ne Avustralya'nın ne de Türkiye'nin inşaatla ilgili yönetmeliklerinde dolu yükü } \\
\text { için herhangi bir tavsiye bulunmaktadır. Doluya karşı dayanıklılığı belirlemek } \\
\text { için yapılan indentasyon testlerinde genellikle dolu parçaları yerine çeşitli } \\
\text { indentörler kullanılmaktadır. Bu testlerde ana kontrol edilen değişken yüzeyde bir } \\
\text { çukur oluşması için gereken minimum enerjidir. Fakat dolu parçaları karmaşı } \\
\text { hava olayları sonucu gerçekleşmektedir ve çarpışma esnasında kendileri yerine } \\
\text { kullanılan cisimler ile farklı davranışlar sergilemektedir. Dolu parçalarının doğal } \\
\text { yollarla oluşumunu laboratuvar şartlarında gerçekleştirmek, neredeyse } \\
\text { imkansızdır. Bu çalışmanın hedefi, doğal dolu parçalarının hasara yol açan } \\
\text { karakteristik özelliklerini simüle etmektedir. Bazı dolu parçaları, çarpş̧ma } \\
\text { sonrasında iç içe geçmiş kristalleri üzerinden geçen dinamik dalganın gerilime } \\
\text { sebep olan kısmına karşı koyabilmektedir. Bu dolu parçalarını gerilime karşı } \\
\text { kuvveti sıfıra yakın olan saf buz ile simüle etmek imkansızdır. Bu çalışmada } \\
\text { kullanılan buz toplarına mikrofiber ve Polivinil Alkol (PVA) eklenerek gerilime } \\
\text { karşı kuvvet artırılmıştır. Dolu çarpmasını incelemek amacıyla üretilmiş teçhizat } \\
\text { kullanılarak farklı yapay dolu parçası üretim metotları incelenecektir. Önerilen } \\
\text { metotla üretilen ve yoğunluğu, saflığl ve yüzey sürtünme özellikleri doğal dolu } \\
\text { parçalarına yakın olan dolu parçaları, içerdikleri \%12 PVA temelli adhezif } \\
\text { sayesinde yüksek hızlı çarpışmalarda bile tek parça kalabilmektedir. }\end{array}$ \\
\hline
\end{tabular}

\section{The Making of a Hailstone Simulated Realistic Damage}

\begin{tabular}{l}
\hline Keywords \\
\hline Artificial hailstone, \\
CFS panels, \\
PVA fiber, \\
PVA adhesive, \\
Pneumatic pressure gun, \\
Realistic hail damage,
\end{tabular}

\begin{abstract}
Damage associated with hailstorms can be on par with earthquake and wind damage. However, due to low risk to life, there are no recommendations for hail load in construction codes of Turkey or Australia. Tests performed to assess hail resistance usually rely on indenters and use the minimum energy required to initiate a dent as the main controlling criteria. However, hailstones are formed in complicated weather phenomena and they behave differently from their substitutes. Creating natural hailstones in a controlled environment is almost impossible. This study aims to simulate the characteristics of damageinducing hailstones. Hailstones have an interlocking of ice crystals which, in some hailstones, resist the tensile component of a dynamic wave propagating through them after impact. Simulating these hailstones with pure ice, which has almost no tensile strength, is impossible. In this study, microfiber and Polyvinyl Alcohol (PVA) additives are used to increase the tensile strength of the ice balls. With equipment built for inspecting the impact of hailstones, different hail production methods will be assessed. The proposed method with \%12 PVA based adhesive produces hailstones that closely maintain density, uniformity, and surface friction qualities of a natural hailstone can remain intact after impact at high velocities.
\end{abstract}

\footnotetext{
* ilgili yazar / Corresponding author: mehmet.uz@adu.edu.tr
} 


\begin{tabular}{l|l}
\hline Alıntı / Cite \\
\hline Uz, M. E., Yılmaz, G., Bircan, T., (2017). Hasari Gerçekçi Şekilde Simüle Eden Dolu Yapımı, Journal of Engineering \\
Sciences and Design, 5(2), 411-423. \\
\hline Başvuru Tarihi /Submission Date & 08.07 .2017 \\
Kabul Tarihi / Accepted Date & 28.08 .2017 \\
Yayım Tarihi / Published Date & 29.08 .2017 \\
\hline
\end{tabular}

\section{Giriş}

14 Nisan 1999'da Sydney'in güneyinde oluşan dolu fırtınası şehrin doğusunda, merkezi iş merkezlerinin bulunduğu, yerleşim yerlerinde terör estirdi [Steingold vd. ,1999 ve Zillman, 1999]. 1999 Sydney Dolu Fırtınası, şu ana kadar Avustralya'nın sigorta sektörüne maliyeti en yüksek olan doğal afettir. Fırtına tahminen 500.000 tonluk doluyu etrafa saçmıștır. Sigorta tarafından karşılanan zararın toplam maliyeti 1,7 milyar AUD'u geçmiştir sigorta tarafından karşılanmayan zararla birlikte toplam maliyet 2,2 milyar AUD civarıdır. Bu firtınanın maliyeti, 1 milyar AUD'a mal olan 1989 Newcastle Depremi'ni geçmiştir. Fırtına sırasında yıldırım düşmesi sonucu bir kişi hayatını kaybederken, fırtınayla ilişkilendirilen toplam 50 yaralanma mevcuttur [Emergency Management Australia 2003 ve Bureau of Meteorology, 2007]. Dahası, 1967 ve 2003 arasında Avustralya'daki doğal afetlerin toplam ekonomik kaybının \%34'ünün sebebi dolu yağmurlarından kaynaklanmaktadır [Australian Building Codes Board 2010]. Araştırmacıların [Basara vd, 2007; Leslie vd, 2008] tahminine göre dolu yağmurları can ve mal tehlikesini artıracaktır ve iklim değişikliğiyle birlikte dolu yağmurların etkisinin daha da tehlikeli boyutlara ulaşma ihtimali bulunmaktadır. Avustralya iklim modelleri Güney-Doğu kıyısında 2030 senesinde senede 1-2 dolu günü, 2070 yılında ise senede 4-6 dolu günü şeklinde bir artışı öngörmektedir [CSIRO Technical Report 2007]. Türkiye'de yapılan araștırmalarda Türkiye Ulusal Afet Arşivi (TUAA) değerlerine göre 12 doğal afet arasından \%7.2 ile en fazla meydana gelen 4 . doğal afettir. Dolu hasarının 1995-2004 yılları arasında sadece Antalya bölgesinde yol açtı̆̆ı zarar yaklaşık birkaç Milyon YTL (Yılmaz, 2008) iken, 27 Temmuz 2017 de İstanbul'da meydana gelen dolunun yol açtığı zarar 22 bin hasar ihbarı ile yaklaşık 168 Milyon TL'yi bulmuştur (www. Hürriyet.com). Dolu firtınalarının yüksek hasara sebep olma potansiyeli olmasına rağmen, can kaybı ihtimalinin çok az olması ve oluşan zararın genelde sigorta tarafından karşılanması sebebiyle Avustralya'daki inşaat yönetmelikleri dolu firtınalarına değinmemektedir. Aynı zamanda bina giydirmelerinin (mantolama) dolu firtınası için herhangi bir şartnamesi bulunmamaktadır. Fakat, dolu yağmurlarına karşı çelik saclar gibi daha dayanıklı çatı kaplama malzemelerinin kullanımı Australia Building Codes Board (2010) tarafindan önerilmektedir. BRANZ ${ }^{\circledR}$ adına Bengtsson vd. (2007) $0.4 \mathrm{~mm}$ çelik çatı kaplamasının 0.55 mm'ye çlkarılmasının finansal faydalarını analiz etmiştir. 162.000 evin tehlike altında olduğu varsayılarak sözü edilen değişimin her sene 200 adet çatıyı kurtaracağı hesaplanmıştır. Değişimin masrafı 145 milyon AUD olacaktır ve 55 milyon AUD'un kaybını önleyerek toplam maliyeti 90 milyon AUD olacaktır. Fakat bu çalışmadaki çelik sacın kalınlığının artırılmasıyla elde edileceği varsayılan fayda hesaplanırken akma dayanımının artırılması göz önüne alınmadığı gibi optimize çelik profillerinin kullanımı da göz ardı edilmiştir. Çatı kaplamalarına dolu yağmurlarının sebep olduğu zarar hakkında yapılan kapsamlı bir çalışmanın yokluğu, birinci yazar tarafından yürütülen Wollongong Üniversitesinde binaların çelik giydirmelerine isabet eden dolu tanelerinin sebep olacağı sonuçları incelemek için bir dizi deneysel tasarımlar oluşturmaya sevk etmiştir [Maguire, 2014; Uz, 2014]. Şu anki dolu tanelerinin çatı kaplamalarında sebep olduğu hasarın tayini hakkındaki araştırma projesi Wollongong Üniversitesi'nde Maguire [2014] ve Uz [2014] tarafından uygulanan test düzeneklerini kullanmaktadır ve ${ }^{4}$ Adnan Menderes Üniversitesinde bu çalışmaya devam edilmektedir.

Ancak, bina bileșenlerini doğru bir şekilde değerlendirme kabiliyeti, dolu tanelerinin sebep olduğu hasarın gerçekçi bir şekilde simüle edilmesine bağlıdır. $\mathrm{Bu}$ sebeple, araştırmanın ilk kısmı laboratuvar ortamında gerçeğe yakın dolu tanelerinin üretimine odaklanmıștır ve bu makalede elde edilen veriler nakledilecektir. Dolu taneleri farklı şekillerde, farklı boyutlarda ve farklı dayanıklılıklarda olabilmektedir. Sadece yüksek limit hızlarda bütünlüğüü koruyabilen dolu taneleri dikkate değer hasarlara neden olmaktadır. Bu özelliklere sahip bir dolu tanesi, cismin rüzgar etkisiyle yukarı ve aşağı birkaç kez hareket etmesiyle oluşur. Genel kanaate göre yüksek sıkışmaya ve gerilmeye karşı dayanıklılığın arkasında oluşan buz kristallerinin iç içe geçmiş yapısı vardır. Dolu tanesi ve çelik panel arasında gerçekleşen dinamik çarpışma sonucunda, dolu tanesinin içinden geçen dinamik dalgalar, sadece en dayanıklı dolu tanelerinin dayanabildiği bir çekme yükü oluşturur. Bu çalışma, bu dolu tanelerinin en iyi temsilcisini bulmayı hedefleyen sistemli bir çalışmadır. Kullandığımız sistem, Dünya'daki dolu yoğunluğuna ve darbe dayanımına sahip olabilecek maddelerin araştırılması, yayınların takip edilmesi ve muhtemel malzemelerin tarafımızdan sürekli deneme yoluyla bulunmasıdır. Araştırma PVA temelli adhezif ve mikrofiber katkıların, yapay dolu tanelerinin sıkışma ve çekme kuvvetini artırdığını keşfetmiştir. Oluşan dolu taneleri, dinamik dolu tanesi çarpışmasını test etmek maksadıyla üretilmiş teçhizatla dinamik çarpışma testine tabi tutulmuştur. 
Makale, çalışma sırasında üç farklı dolu tanesi üretme metodu keşfedildiğini ve her metodun en iyi sonuçları verecek işlemleri ve dolu tanelerinin içerdikleri malzeme miktarlarını göstermektedir. Bu çalışma, özellikle yapay dolu tanesi üretim işlemine odaklanan ilk çalışmadır. Aynı zamanda 50 mm'ye kadar bir çap uzunluğunda ve $50 \mathrm{~m} / \mathrm{s}$ çarpışma hızında bütünlüğünü koruyacak yapay dolu tanelerini üretmek için bir metodu ortaya koyan ilk çalışmadır. Daha önemlisi, yapay dolu taneleri bu dayanıklılığa, doğal dolu tanelerinin diğer fiziksel özellikleri fazla değişmeden ulaşabilmiş olmasıdır. Bu makalenin ilk bölümü yapay dolu üretim tekniğinin şu anki vaziyetini özetler. Bu bölüm aynı zamanda doğal dolu tanesi oluşum sürecinin karmaşıklığını ve doğal dolu tanelerinin karakteristik özelliklerini gösterir. Bir sonraki bölümde şu anki yapay dolularla yapılan dolu simülasyon prosedürleri ve bileșenleri açıklandığı gibi, dolu deneylerini etkileyen standartlar hakkında da bahsedilecektir. Üçüncü bölüm temsili dolu tanelerinde aranan nitelikler hakkındadır. Üçüncü bölümdeki alt bölümler yapay dolu tanesinin yapımı hakkındadır. Dördüncü bölüm dinamik dolu testi yapılış yöntemi ve değerlendirme prosedürleri hakkındadır. Beşinci bölümde üretilen yapay dolu tanelerinin nitelikleri gösterilmiş ve karşılaştırılmıştır. Son bölümde sonuçlar özetlenmiş ve sunulmuştur.

\section{Yapay Dolu Tanesi Üretimindeki En Yeni Teknoloji}

Doğal dolu taneleri arasında yoğunlukları, şekilleri, limit hızları, yüzey sürtünmeleri ve erime hızları gibi birçok nitelik bakımından müthiş farklar vardır. Bir fırtınanın getirdiği çok sayıdaki dolu tanesinin sadece ufak bir kısmı çatı malzemeleri ve araç panellerine zarar verebilecek boyut, şekil ve dayanıklılığa sahiptir. Gerçek dolu hasarını simüle edip edemeyeceği şaibeli olan, çok sayıda dolu içeren bir fırtına üretmek ne ekonomik olarak kabul edilebilirdir, ne de pratikte mümkündür. Ayrıca, dolu oluşumunun karmaşık işlemini laboratuvar ortamında gerçekleştirmek neredeyse imkansızdır. Dolu fırtınalarının etkilerini daha iyi anlayabilmek için ilk kez kapalı ve kontrollü laboratuvar ortamında, tam ölçekli bir dolu fırtınası Institute for Business and Home Security (IBHS), tarafından oluşturulmuştur [IBHS 2013]. Bu deneyde yaklaşık $8000-10000$ adet $25.4 \mathrm{~mm}, 38.1 \mathrm{~mm}$ ve 50.8 mm boyutların dolu kullanılmış ve saatte $122 \mathrm{~km} / \mathrm{saat}$ hız ile atılmıştır. Fakat üretilen buz topları, bu makalede de açıklanacağı gibi, ne doğal dolu tanesi oluşum sürecini temsil edebilmiş ne de hasara sebep olan tanelerin dayanıklılığına ulaşabilmiştir.

\section{1. Doğal Dolu Oluşum Süreci}

Dolu, şiddetli gök gürültülü fırtınalarda oluşan belirli bir yağış türüdür. Dunlop (2008)'a göre dolu, "çapı 5 mm'den fazla olan buz topları"dır. Dolu, bir kümülonimbus bulutunun yukarı çekişine takılan, "embryo" adı verilen, küçük bir parçacı̆̆ın büyümesiyle oluşur. Embriyolar genellikle "nuclei" adı verilen küçük buz kristallerinden oluşur fakat embryolar bazen de toz parçacıkları ve hatta böcekler bile olabilmektedir [Engelbert 1997]. Embryo bulut içinden ilerlerken "akresyon" adı verilen bir süreçten geçerek boyutu büyür. Dolu tanelerinin kütlesi arttıkça bulutun altına doğru ilerlemeye başlarlar. Eğer dolu yeterince büyükse yağıș olarak buluttan düşer. Fakat kuvvetli fırtınalarda dolu taneleri düşmek yerine yukarı çekime takıldıktan sonra birkaç kez buluta girip çıtıktan ve kütlesini yeterince arttırdıktan sonra ancak yeryüzüne düşebilmektedir. $\mathrm{Bu}$ olay aynı zamanda bir sıcak hava olayıdır yani bulutların altındaki hava sıcaklığı suyun erime noktasının altındadır.

Böylece dolu tanesi, inişi sırasında erir. Küçük dolu taneleri tamamen eriyip su damlaları olarak yeryüzüne düşebilir. Daha büyük dolu taneleri ise katı bir halde düşerler ve binalara, altyapıya, araçlara, tarıma ve hayvanlara zarar verebilir. Donmuş damla embryoları ve Graupel embryoları iki tipik embryodur [Hile, 2009; Oard, 2015]. Donmuş damla embryoları saydam görünümlü, içinde fazla hava kabarcığ bulunmayan donmuş yağmur damlalarından olușur ve genellikle çapları 1.5 mm'den fazla iken, Graupel embryoları içinde daha fazla hava kabarcı̆̆ının bulunduğu buz kristallerinden oluşur ve içerdiği hava kabarcıkları yüzünden beyaz renkte görünür [Knight ve Knight, 1976; Michaud vd., 2014]. Lru (1979)'nun bulgularına göre tatlı sudan oluşan buzun parça sertliği, düşük sıcaklıkta ve düşük yükleme hızında artış gösterir. Parçacık boyutunun da buz dayanıklılığına etkisi vardır [Sain ve Narasimhan, 2011].

Dolu tanelerinin \%75'inden fazlasının küresel şekilli olduğu Crenshaw ve Koontz (2002) tarafindan keşfedilmiştir.Bir dolu tanesinin ortalama yoğunluğu $0.91 \mathrm{~g} / \mathrm{cm}^{\prime}$ tür [Brimelow vd. 2002; Crenshaw ve Koontz 2002]. Dolu tanesinin katmanlarının opaklık farkının en önemli sebebi dolunun oluştuğu buluttaki sıcaklık ve nem değişiklikleridir [Nelson 1983; Brimelow vd. 2002]. Şeffaf ya da yarı șeffaf katmanlar genellikle dolu tanesinin islak büyüme sonucu bir katman daha elde etmesinin sonucudur [Pflaum 1980 ve Nelson 1983]. Kuru büyüme ise dolu tanesi, sıcaklığ $1-40 \quad{ }^{\circ} \mathrm{C}$ 'nin altında bulunan bir hava tabakasından geçince, havadaki nemin dolu tanesi üzerinde yoğunlaşmasıyla gerçekleşir. Beyaz, bulanık, opak katmanlar su buharının dolu tanesi üzerinde yoğunlaşmasıyla oluşur [Nelson 1983 ve Farley vd. 2004]. Bu katmanların enine kesiti -tıpkı ağaçlarda görüldüğü gibi eș merkezli halkalar görünebilir. Doğal dolu tanesinin birbirinden farklı halkaların diziliminden olușması, doğal dolu tanesinin niteliklerini taklit edecek yapay dolu tanelerinin üretilmesi önünde bir engeldir.

\subsection{Dolu Çarpmasını Test Etmede Var Olan Metotlar}


Dolu çarpmasını inceleyen çalıșmalar genellikle bina malzemeleri, kara ve hava araçlarının gövde panelleri üzerine odaklanmıştır. Çelik yüzeyin dolu tanesi hasarına karşı dinamik çarpışma direncinin bulunması, genellikle statik ya da yarı statik yükleme şartları altında uygulanan çelik yüzeyde çukur oluşumu testlerine dayanır. $\mathrm{Bu}$ araştırmalar gözle görülebilir bir çukur oluşturmak için gereken minimum kuvveti ya da enerjiyi hesaplamaya yöneliktir.

Materyallerin doluya karşı dayanıklılığına ve dolu çarpışmasını test etmenin en yaygın metotları, test edilecek materyal üzerine çelik toplar, çelik dartlar, delici uçlar ya da küresel buzların serbest düşüşünü veya pnömatik itișini içerir. Fakat bu metotların gerçeğe yakın dolu hasarıyla herhangi bir ilişkisi ispatlanamamıştır. Çelik toplar, çelik dartlar ve delici uçların çarpışma anındaki davranışlarının birbirinden çok farklı olduğu unutulmamalıdır. Ama saf buz topları, herhangi bir çekme kuvveti içermediklerinden dolayı çarpışma anında kırılmaktadırlar. Literatürde dolu isabet simülasyonlarının örnekleri bulunmaktadır. Bazı araştırmacılar çelik ya da başka bir tür indentörü havadan serbest bırakmayı denemișlerdir [Johnson ve Schaffnit, 1973; Nomura vd., 1984; Vreede vd., 1995; Fleming vd., 1997; Shi vd., 1997; McCormick vd., 1998; USS, 2005]. Araştırmacıların hatırı sayılır bir miktarı numunelere, pnömatik basınçla cisimleri itecek bir çeşit gaz silahı metodunu denemişlerdir [Johnson ve Schaffnit, 1973; Moore ve Wilson, 1978; Nomura vd., 1984; Vreede vd., 1995; Fleming vd., 1997; Shi vd., 1997; McCormick vd., 1998; USS, 2005]. Bașka bir yaklașım da bir indentörün kullanıldığı bir yer değiștirme kontrolünün uygulandığı metottur [Moore ve Wilson, 1978; Chang ve Khetan, 1984; Paterson ve Sankaran, 1994; Kim ve Kedward, 1999; Kim vd., 2003; Flüeler vd., 2008; Lavoie vd., 2011 ve Tobias vd., 2014]. Yukarıdaki çalıșmalarda bahsi geçen yapay dolu tanelerinin bileşenleri çelik indentörler, çelik toplar, kardan üretilen buzlar, buz parçacıkları, katmansız buzlar ve katmanlı buzlardır. Aynı zamanda masa tenisi topuna enjekte edilmiş su, demineralize su, Polivinil Alkol temelli Polikristalin buz, buz tanelerinden katmanlı buz, tatlı su, distile edilmiş su ve buz toplarına karıștırılmıș pamuk da kullanılmıștır. Swift (2013), buz topunun parçalara ayrılmasını önlemek için pamuk liflerini kullanmıştır.

Geoffrey Pyke'ın İkinci Dünya Savaşı sırasında ürettiği Pykrete'e benzer bir konsept kullanılmıştır. Pykrete, erime hızı içerdiği \% 14'lük tahta lifleri ya da talaş sayesinde çok düşük olan bir buz parçasıdır. Swift (2013)'in bulgularına göre pamuklu buz topunun sünekliği pamuksuz olanınkinden çok daha fazladır. Yarı statik metot (gerinim hızının kontrolü) kullanılınca pamuksuz buz topunun pamuklu toptan daha erken parçalandığı gözlemlenmiştir. Fakat bu pamuk lifli buz topunun, homojen olmama ve yüzey sürtünmesinin her yerde aynı olmaması gibi sorunları vardır.

Ayrıca, bu yapay dolu tanelerinin çapları 25 mm'den büyük olursa çarpıșma esnasında bir parçasının koptuğu gözlemlenmiştir.

\subsection{Dolu İsabet Testleri İçin Var Olan Standartlar}

ASTM D3746 (1985), çatı sistemlerinin doluya karşı dayanıklılığını, çatı kaplama malzemesi örneğine 25 mm çaplı yarıküresel başlıklı 2.27 kg'lık çelik bir cismi havadan serbest bırakarak ölçmektedir. Cisim, 1350 mm yükseklikten bırakılır ve 30.0 J'lük bir enerjiyle çarpmaktadır. Hasar değerlendirmesi görsel izlenimlere dayanır. ANSI/FM 4473 (2011), kaplama malzemelerinin çarpmaya karşı direncinin değerlendirmesi $28.1 \mathrm{~mm}, 31.8 \mathrm{~mm}, 44.5 \mathrm{~mm}$ ve 50.8 mm çaplı buz toplarını kullanarak yapmaktadır. Buz topları seçilen hedefin kinetik enerjisinden \%10'dan az bir miktar daha fazla bir kinetik enerjinin oluşmasına sebep olacak şekilde ilerlemektedir.

Dolu tanesini değerlendirmek için kinetik enerjinin bir parametre olarak kullanılması, yeterli bir araştırmadan yoksundur ve doğal dolu tanelerinde her zaman görülmeyen kütle ve hızın karesi arasında bir ilișkinin bulunduğunu varsaymak olacaktır. Bu bir yana, test edilen malzemeye aktarılan enerji ve enerji kaybı ne ölçülmüş, ne de tahmin edilmiştir [Krenshaw ve Koontz, 2001]. Bu bir yana, FMRC dolu firtınasına maruz kalabilecek çatı kaplamaları için sertifikasyon programları yürütmektedir. FMRC'nin test metotları da test edilecek örneklere çeşitli yükseklikten bırakılan çelik topları kullanmaktadır.

Benzer bir şekilde, Underwriters Laboratories (UL) de çatı panelleri ve membranları için çarpışmaya karşı dayanıklılı sertifikaları vermektedir. UL'de uygulanan metot da dört ayrı boyutta çelik topunun farklı yüksekliklerden çatı panellerine bırakılmasını içermektedir. Yeni çatı kaplamalarına yapılan testler genellikle ortam sıcaklığında yapılmaktadır. Factory Mutual Research, The Canadian Standards Board (CGSB) ve The European Genreal Agreement Board (EGAB) gibi organizasyonlar da dolu hasarı değerlendirme çalışmalarına katkı sağlamaktadırlar. Şu anki standartların kullanıldığı değerlendirmeler, zarar verici nitelikteki dolu tanelerinin karakteristik özelliklerini simüle etmede başarısız oldukları için güvenilir değillerdir. Doğal dolu taneleri ve yapay dolu taneleri arasındaki uçurumun kapatılması için sıkı bir çalışmaya ihtiyaç vardır.

\section{Dolu Tanesinin Gerçekçi Olması için Kriterler}

$\mathrm{Bu}$ çalışma hasarı gerçekçi bir şekilde simüle edecek bir dolu tanesinin bazı karakteristik özelliklerini inceleyecektir. İlk olarak, dolu tanesinin büyük çoğunluğu buzdan oluşmalıdır. İkinci olarak, dolu tanesinin nitelikleri tanenin her yerinde aynı olmalıdır. Üçüncü olarak, üretilen dolu taneleri kullanılırken çarpışan yüzeyler arasında gerçekçi bir 
sürtünmenin simülasyonu için doğal dolu tanelerinde görülen yüzeyde erime davranışı görülmelidir. Son ve en önemli karakteristik özellik ise üretilen dolu tanelerinin hedeflenen limit hızda isabet ettikten sonra bütünlügünü korumalarıdır. $\mathrm{Bu}$ kriterlerin seçimi arkasındaki sebepler şunlardır: İlk kriter şu an kullanılan çelik ve plastik toplar gibi buzdan tamamen farklı davranan maddelerin kullanımından doğan belirsizlikleri kısıtlamaktadır.

İkinci kriter, panel üzerinde oluşacak çukurun dolu tanesinin isabet ettiği yöne veya tanenin oryantasyonuna bağlı olarak değişmemesini sağlamaktadır. Üçüncü kriterin sebebi ise doğal dolu tanelerinin yer yüzüne düşerken sıcaklıktan dolayı yüzeyin eriyip ve böylelikle yüzey sürtünmesinin çok küçük bir değere çekilmesidir. Son olarak, en kuvvetli dolu taneleri bütünlüklerini limit hızda çarpışmadan sonra korumaktadır. Küçük parçalara ayrılan dolu taneleri parçalanma esnasında enerjiyi dağıtıp çelik panele aktarılan enerjiyi azaltacaktır.

\subsection{Yapay Dolu Tanesi Üretimi için Kalıplar}

Yapılan testte farklı boyutlarda buz topları üretmek için birden fazla plastik kalıp kullanılmıştır. En yaygın boyutlar $25 \mathrm{~mm}, 33 \mathrm{~mm}, 45 \mathrm{~mm}$ ve $50 \mathrm{~mm}$ 'dir. Şekil 1, Şekil 2 ve Şekil 3 sırasıyla $25 \mathrm{~mm}, 33 \mathrm{~mm}$ ve $45 \mathrm{~mm}$ çaplı kalıpları göstermektedir. Tüm dolu taneleri tek parça halinde küresel kalıplarla dökülmüştür ve en az 6 saat boyunca dondurulmuştur. Dolu tanelerinin tamamen donması için gerekli asgari süre Rhymer (2012)'nin bulgularına dayanmaktadır. Genelde kalıptan çlkarma işlemi en az 24 saat sonra yapılmaktadır. Daha sonra buz topları testlerden önce bir hafta kadar daha dondurulmaktadır.

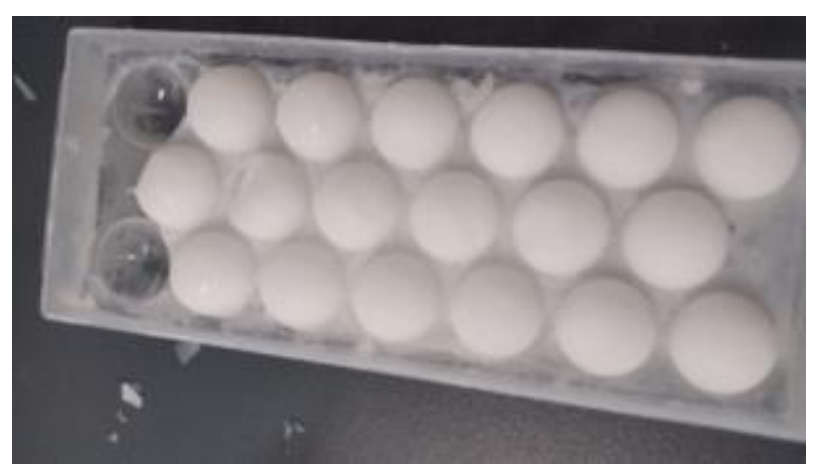

Şekil 1. $25 \mathrm{~mm}$ plastik dolu kalıbı

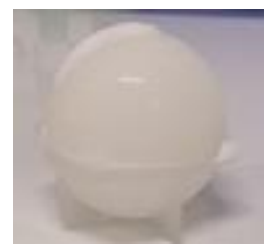

Şekil 2.33mm plastik dolu kalıbı

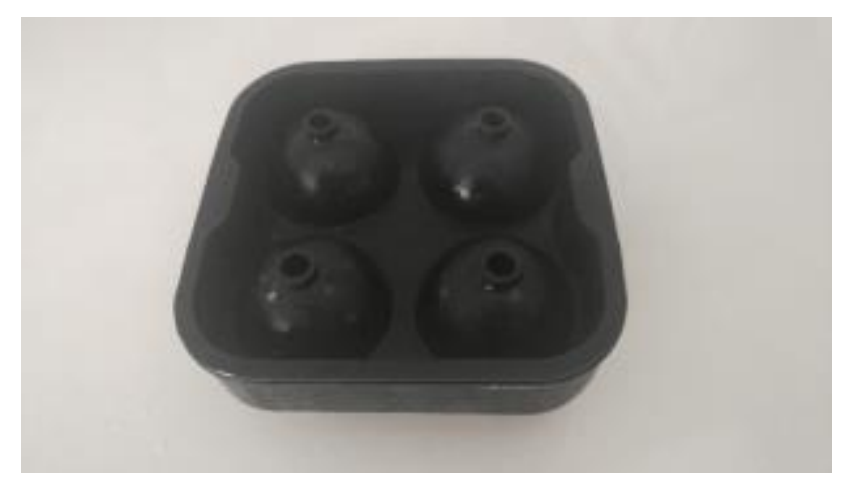

Şekil 3. 45mm plastik dolu kalıbı

Maguire (2014) ve Uz vd. (2014) 'un buluşlarına göre dolu tanesinin boyutu arttıkça erime hızı da düșmektedir. Aynı zamanda erime hızı zaman geçtikçe artmaktadır. Bu yüzden erimeyi azaltmak ve sonuçların gerçeğe uygunluğunu en yüksek seviyede tutmak için, dolu tanelerinin ortam sıcaklığında iki dakikadan fazla tutulmaması tavsiye edilmektedir. Dolu tanesi isabet deneyi yapılırken bu tavsiye göz önüne alınmıştır. Dolu hasarı üzerine yapılmış çoğu çalışma, Tablo 1'deki Laurie (1960)'nin bulduğu limit hız değerlerini kullanmaktadır. Maguire (2014) ve Uz vd. (2014) şu anki çalıșmaya benzer bir șekilde ürettiği yapay dolu taneleriyle bu değerleri deneysel olarak kanıtlamıştır.

Tablo 1. Dolu Terminal Hızları (Laurie, 1960)

\begin{tabular}{|c|c|c|}
\hline Çap (mm) & $\begin{array}{c}\text { Terminal } \\
\text { Hız (m/s) }\end{array}$ & $\begin{array}{c}\text { Yaklaşık Çarpma } \\
\text { Enerjisi (J) }\end{array}$ \\
\hline 25 & 22.3 & $<1.4$ \\
\hline 32 & 25.0 & 5.4 \\
\hline 38 & 27.4 & 10.9 \\
\hline 45 & 29.6 & 19.0 \\
\hline
\end{tabular}

\subsection{Yapay Dolu Tanesi Üretiminin Bileşenleri}

Bu çalışma yapay dolu tanesi üretmek için yapılmış birçok metodu incelemiştir. Saf buz elde edilen, katmanlı, saflık derecesi az, saflık derecesi fazla gibi sonuçlar elde edilen metotlar incelenmiştir. $\mathrm{Bu}$ çalışmada en uygun kombinasyonu bulmak için farklı mikrofiber (Şekil 4) ve PVA temelli adhezif maddeler (Şekil 5) karışımlarını keşfedilmiștir. Bu makale her kombinasyonda en iyi sonucu verecek üç metodu gösterecektir. Uygulanan bu metotlar: 1)Saf sudan dolu elde edilmesi. 2)Saf su ile birlikte \% 1 mikrofiber ve \%5PVA karıștırılıp yapay dolu elde edilmesi. 3)Saf su ile birlikte \%12 PVA kullanılarak yapay dolu elde edilmesidir. Yaptığımız deneylerin sonuçlarına göre saf sudan yapılan buzun yoğunluğu $0.97191 \mathrm{~g} / \mathrm{cm}^{3}, \%$ mikrofiber ve \% 5 PVA karışımlı dolunun yoğunluğu $0.97679 \mathrm{~g} / \mathrm{cm}^{3}, \% 12$ PVA içeren dolu için yoğunluk $0.94883 \mathrm{~g} / \mathrm{cm}^{3}$ olarak ölçülmüştür. Şekil $6 \mathrm{bu}$ metotlarla üretilen dolu tanelerini göstermektedir. Buzdan ibaret olan dolu tanesi saydam; hem mikrofiber hem de PVA içeren beyaz; sadece PVA içeren ise hafif pembe renklidir. İlerleyen bölümlerde dolu tanesi üretmek için uygulanan metotlar adım adım açıklanacaktır. Bütün metotlarda dondurucu sıcaklığı $-12{ }^{\circ} C^{\prime}$ dir. Bunun sebebi dolunun bu 
sıcaklıkta bütünlüğünü koruması ve dolu davranışını bütünüyle göstermesidir.

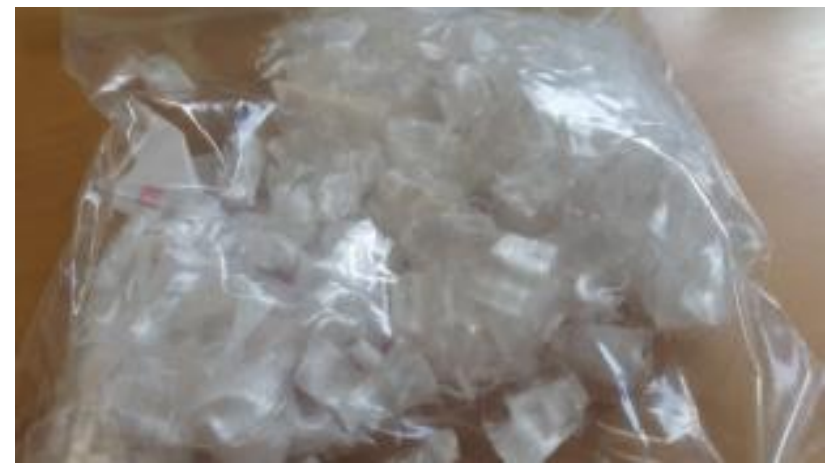

Şekil 4. Mikrofiber

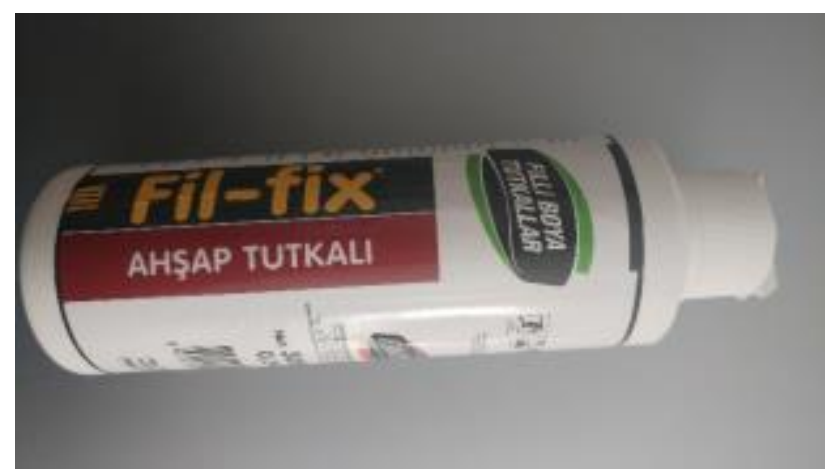

Şekil 5. PVA temelli adhezif madde karışımı

\subsubsection{Saf Buz Dolu Taneleri Oluşturmak için Uygulanacak Adımlar \\ Saf buz dolu taneleri oluşturmak için uygulanacak prosedür aşağıdaki gibidir:}

1. Soğutma kutusuna fazla bir miktar demineralize su koyun.

\section{Kalıbı demineralize suyla doldurun.}

3. Kalıbı soğutma kutusu içindeki suya yerleştirin ve deliklerin soğutucunun altına bakması için kalıbı çevirin. Eğer su dolu kalıp su üstüne çıkmazsa kalıbı yukarıda tutmak için bir huni kullanın. Kalıp suyun dibinde değil, sadece havaya temas etmeyecek șekilde suyun altında bulunmalıdır.

4. Soğutucuyu içindeki kalıbın suyun dibine batmaması için titretmeden dikkatli bir şekilde dondurucuya yerleştirin.

\section{Soğutucuyu en az dört saat dondurucuda bekletin.}

6. Soğutucuyu çıkarın, dondurucunun dışında en az 60 dakika bekletin, sonra da buz bloğunu soğutucudan çlkarın.

7. Kalıba hasar vermeden buz bloğunu çekiç ve ıskarpela yardımıyla kırın.

\section{Parçalanmış buzun içinden kalıbı çıkarın.}

9. Buz topunu kalıptan çıkarın.
10. Kalıbın giriş deliğinin yakınında oluşan hava kabarcıklarını parmakla ovalayarak düzeltin.

\section{$3.2 .2 \% 1$ Mikrofiber ve \%5 Polivinil Alkol İçeren} Dolu Tanesi Üretmek için Gerekli Ek Adımlar

\%1 mikrofiber ve \%5 PVA içeren dolu tanesi üretmek için uygulanacak prosedür aşağıdaki gibidir.

1. Havanın çıkması ve çözünmeyi hızlandırmak için demineralize suyu iki kez kaynatın.

2. Gerekli PVA ve mikrofiber miktarı hesaplayıp karıștırma tasına yerleștirin.

4. PVA miktarını \% 5 yapmak için gerekli kaynamış su miktarını hesaplayın.

5. Suyu karıştırma tasına ekleyin ve karışımın tamamen çözünmesi için en az 20 dakika boyunca karıştırın.

8. Çözeltiyi bir șırınga yardımıyla farklı boyutlu kalıplara \% 5 kadarlık hacimleri boş bırakarak (karışımda Polivinil Alkol bulunduğu için bırakılan değer genelde kullanılan \% 10'dan daha düşüktür) doldurun.

9. Saf buzdan oluşan dolu tanesi üretmek için gerekli 3. adımdan 9. Adıma kadar olan kısmı takip edin.

\subsection{3. \%12 PVA İçeren Dolu Tanelerinin Üretilmesinde Uygulanacak Ek Adımlar}

İzlenecek adımların Bölüm 3.2.2' de verilen adımlarlar ile tek farklılığı bölüm 3.2.2' de \%1 mikrofiber ve \%5 PVA kullanılırken, bu bölümde \%12 PVA kullanılmasıdır.

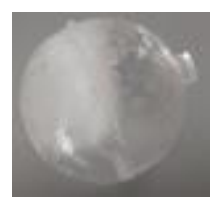

a) saf buz dolu tanesi

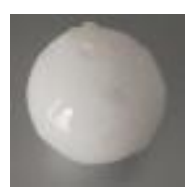

b) $\% 1$ mikrofiber ve \%5 PVA içeren dolu tanesi

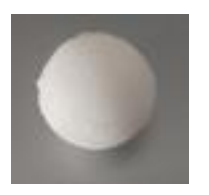

c) $\% 12$ PVA içeren dolu tanesi
Şekil 6. Bu çalışmada kullanılan farklı dolu tanesi

\section{Dinamik Dolu Tanesi İsabet Deneyi}

Test, Maguire (2014) ve Uz (2014) 'in dinamik dolu tanesi isabet testini temel almaktadır. Dinamik dolu tanesi isabet testi, ikamet edilen binaların çelik çatı kaplama malzemelerle benzer nitelikte çelik yüzeylere dolu tanelerinin pnömatik itișle yatay atılmasına izin verecektir. Deneylerde dolu tanelerinin kütlesi, boyutu, çarpıșma öncesi hızı ve sebep olduğu çukurun çapı ve derinliği kaydedilecektir. Testin yatay biçimde gerçekleştirilmesi ile dikey biçimde gerçekleştirilmesi karşılaştırıldığında teçhizat karmaşıklığı ve güvenliğe karşı oluşan risk azalmaktadır ve deneyi gerçekleştirmek kolaylaşmaktadır. Dolu tanelerinin dikey bir şekilde çelik örneğine atılması, doğal dolu tanelerinin isabetlerine benzer şartlar sağlasa da fazla 
bir fayda elde edilemediği bulunmuştur [Maguire, 2014]. Yatay atılmış dolu tanesi isabet deneyi Niemeier ve Reynolds (1978), Moore ve Wilson (1978), Chang ve Khetan (1984), Patersonve Sankaran (1994), Crenshaw ve Koontz 2002, Tippmann (2011) ve Rhymer (2012) tarafından başarılı bir şekilde gerçekleştirilmiştir.

\subsection{Dinamik Dolu Tanesi Deneyi Amaçlı Üretilmiş Teçhizat}

Dinamik dolu tanesi deneyini gerçekleștirmek için kullanılan teçhizat Uz (2014) tarafından tasarlanmış ve üretilmiştir. Deney teçhizatı diğer malzemelerle birlikte bir dolu tanesi atıcl, dolu tanesi tutucu, koruma ünitesi ve en az saniyede bin kare (1000fps) kayıt alabilen bir yüksek hızlı kameradan oluşmaktadır. Doğal şartların iyi bir şekilde temsil edilebilmesi için teçhizat, amaca uygun bir şekilde üretilmiştir. Dolu tanesi atıcı basınçlı havayı kullanmak için bir hava kompresörü, atıştan önce belirtilen basıncı tutması için bir basınçlı hava tankı ve Şekil 7'de gösterildiği gibi bir çelik namludan oluşur. Dolu ateşleme makinası çelik bir tüpten ve dolu tanesini itmek için bir pistondan oluşmaktadır.

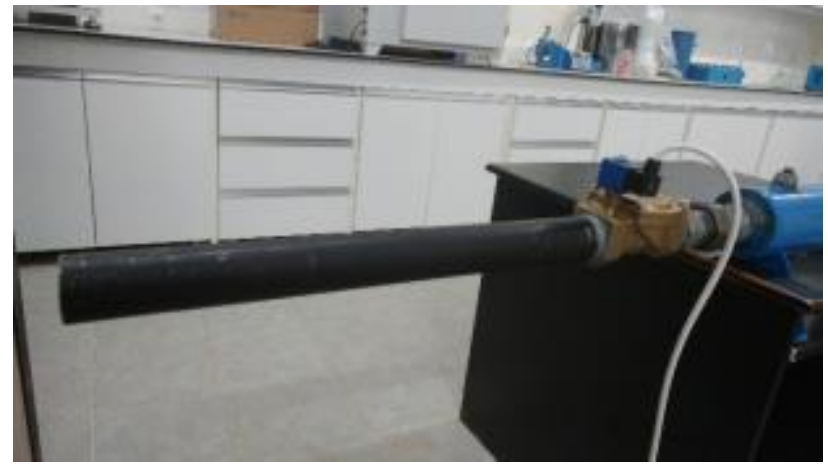

Şekil 7. Namlu Yeri

Namlu, AS1210'ın basınçlı tanklar için geçerli şartnamesine göre yapilmıștır. Dolu tanesi tutucu (Şekil 8) çelik manşonun ön tarafına bir cıvata ve rondelayla sabitlenmiştir. Dolu tanesi tutucusu namlunun içine yerleştirilmiş bir PVC silindirden oluşmaktadır. Dolu tanesinin hızlanması sırasında zarar görmesini engellemek için tutucu ve dolu tanesi arasında bir miktar yüksek yoğunluklu köpük bulunmaktadır. Koruma ünitesi dolu tanelerini güvenli bir şekilde içinde tutar ve deney esnasında dışarıdan duyulacak sesi azaltmaktadır. (Şekil 9 ve Şekil 11).

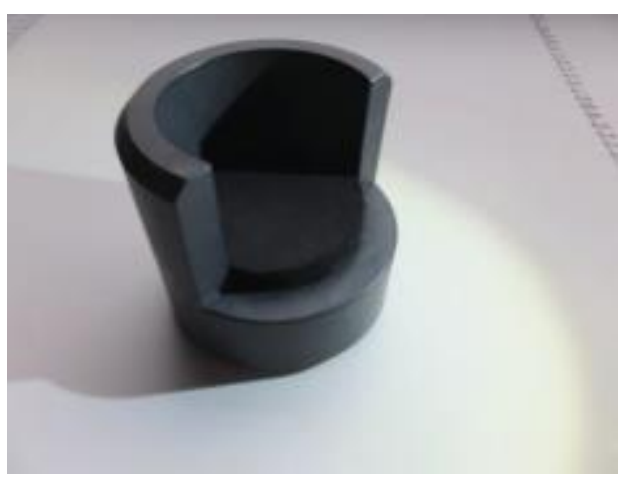

Şekil 8. Dolu tanesi tutucu

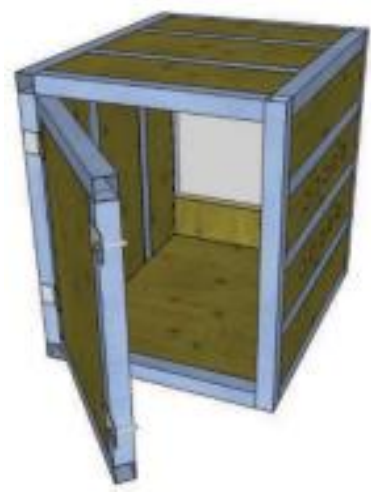

Şekil 9. Koruyucu ünite tasarımı ön cephe
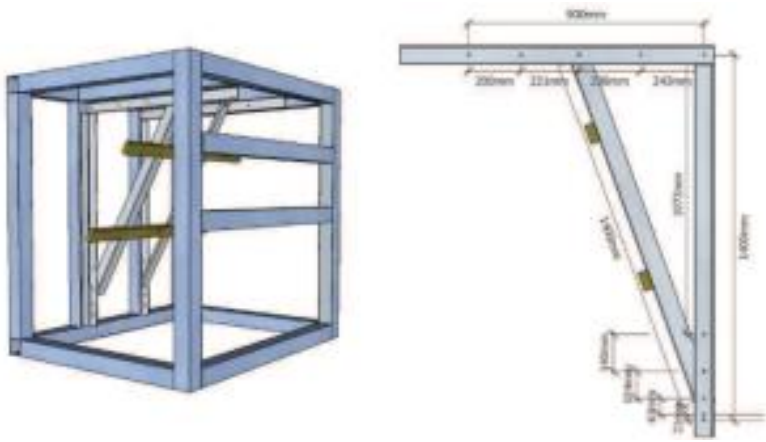

Şekil 10. Çelik kafes çerçevesi

Aynı zamanda, dolu tanesi atıcı namlusuna birden fazla giriş noktası sağlamaktadır ve namlu için biçimi bozulmayacak bir yerleștirme noktası sağlar. Şekil 10, çatı panellerinin yerleştirilme şemasını göstermektedir. Koruma ünitesinin etrafi sunta tabakalı akustik yalıtım malzemesiyle çevrilidir. Bu katmanlı duvarlar ve tavan, seken dolu taneleri karşısında mekanik bir bariyer oluşturmaktadır. Aynı zamanda, akustik yalıtım atıcıdan boşalan basınçlı havanın ve dolu tanesiyle çelik örneğin çarpışmasının sebep olduğu sesi azaltmaktadır. $200 \mathrm{~mm}$ ortada 100 mm çaplı iki sıra şeklinde 10 tane giriş noktası bulunmaktadır. 


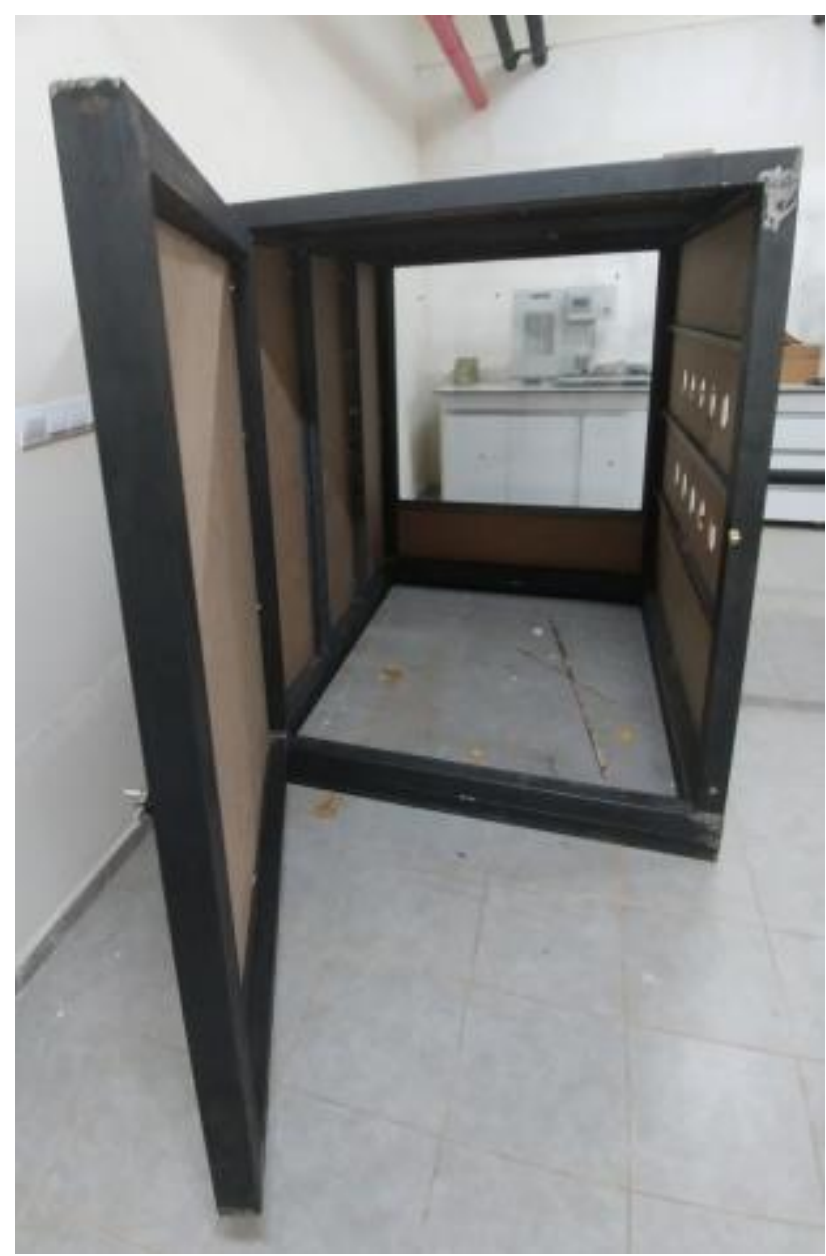

Şekil 11. Koruyucu ünite iç kısım

Yüksek hızlı kamera (Şekil 12) çarpışma yönünün normaline yerleștirilerek çarpışmadan hemen önce, çarpışma esnasında ve çarpışma sonrasında buz toplarının durumunu belirlemede kullanılmıștır. Bu durum sayesinde, dolunun hızı ve darbeye karşı davranışı gözlemlenmiştir. Şekil 13 test düzeneğini göstermektedir.

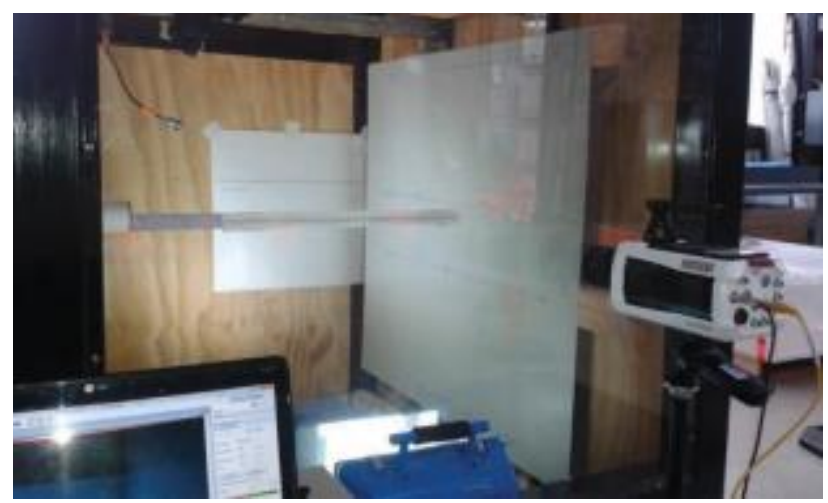

Şekil 12. Yüksek hızlı kamera kurulumu

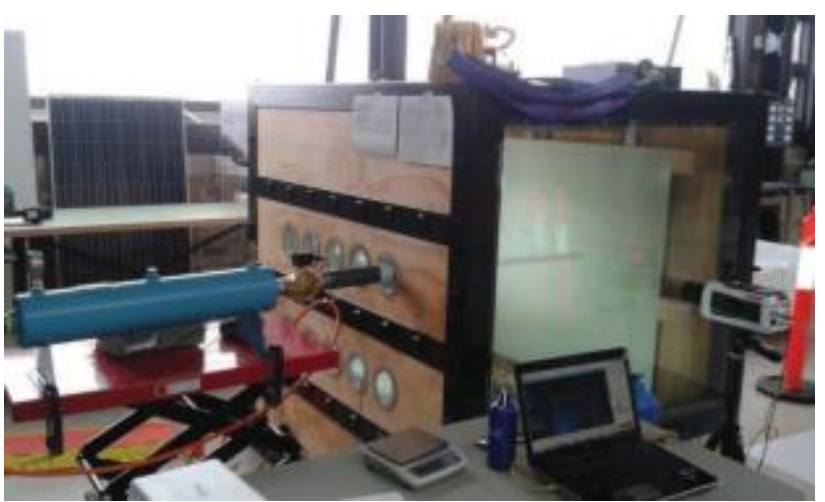

Şekil 13. Test düzeneği

\subsection{Dinamik Dolu Tanesi Çarpışma Testi Prosedürü}

Dinamik Dolu Tanesi Çarpışma Testinin prosedürü şöyledir:

1. Hava kompresörünü çalıștırın ve dolu tanesi atıcının yanına yerleştirin.

2. Çelik sac numunesini koruma ünitesi içindeki çerçeveye yerleştirin ve istenen eğime getirin.

3. Koruma ünitesinin kapısını kapatıp kilitleyin.

4. Dolu tanesi atıcıyı, namlusu istenen giriş noktasından çıkacak şekilde yerleştirin.

5. Yapay dolu tanesini dondurucudan çıkarıp kütle ve boyutlarını kaydedin.

6. Atıcıyı geriye kaydırın ve dolu tanesini tutucuya yerleștirin.

7. Atıcının namlusunu tekrar giriş noktasına getirin.

8. Hava kompresörünü atıcının giriș supabına bağlayın ve istenen basincı doldurun.

9. Yüksek hızlı kamerayı kullanarak kayda başlayın.

10.Atıcı üzerinde valfi açarak dolu tanesini numuneye atın.

11. Kaydı durdurun ve videoyu kaydedin.

12 Koruma ünitesinin kapısını açın. Oluşan çukurun çapını, derinliğini ve diğer istenen parametrelerini kayıt altına alın. Çelik numuneyi koruma ünitesinden çıkarın.

13. Atıcının basıncını tamamen boşaltın ve hava kompresörüyle bağlantısını kesin.

14. Her numune için 2. Adımdan 10. Adıma kadar olan kısmı tekrarlayın.

15. Oluşan çukurun enini ve boyunu daha doğru hesaplamak için 3 boyutlu tarama kullanın. $\mathrm{Bu}$ 
makalede şu anki çalışmanın dışında olduğu için çelik panellerin detayları belirtilmemiştir.

\subsection{Limit Hızın Hesaplanması}

Yapay dolu tanesinin çarpma hızı yüksek hızlı kamera ve arka planda ölçü çizgileri olan bir beyaz tahta kullanılarak yapılmaktadır. Beyaz tahtanın uzunluğu $90 \mathrm{~cm}$ 'dir ve 90 eșit parçaya ayrılmıștır. Beyaz tahta sekme hızını tahmin etmek için aynı zamanda çelik numunenin yanındadır. Doğru ışıklandırma şartları altında yüksek hızlı kameradan saniyede 2800 kareye kadar bir görüntü alınabilmektedir. Fakat kayıt zamanı azaldıkça dolu tanesinin çarpışmasını kaçırma ihtimali artmaktadır. Bu yüzden şu anki test metodu saniyede 1000 kareyle çekim yapmıştır. Şekil 14'te aynı deney için yüksek hızlı kamerayla çekilmiş görüntülerin biri çarpışmadan hemen önce ve diğeri çarpışmadan sonra çekilmiştir. Testte kullanılan dolu tanesi $40 \mathrm{~mm}$ çapındadır, \%1 mikrofiber ve \%5 PVA'dan oluşmuştur ve 12.5 psi basınçla atılmıştır. Şekil 15'te 8 psi basınçla atılmış, $32 \mathrm{~mm}$ yarıçaplı $\% 12$ PVA içeren dolu tanesinin kullanıldığ benzer bir karşılaştırma görülmektedir. Böyle bir metotla hesaplanan hızın hata payı kabul edilebilir bir miktarda olmakla birlikte \% 1.14'tür. Atışta kullanılan basınç ve hız arasında $33 \mathrm{~mm}$ çaplı yapay dolu tanelerinin test edildiğinde, Şekil 16'da görüldüğü gibi neredeyse doğrusal bir ilişki gözlemlenmiştir. Her buz topunun kalıp boyutu farklı olduğu için her boyuttaki dolu tanesinin kütlesinin yakın beklenebilir.

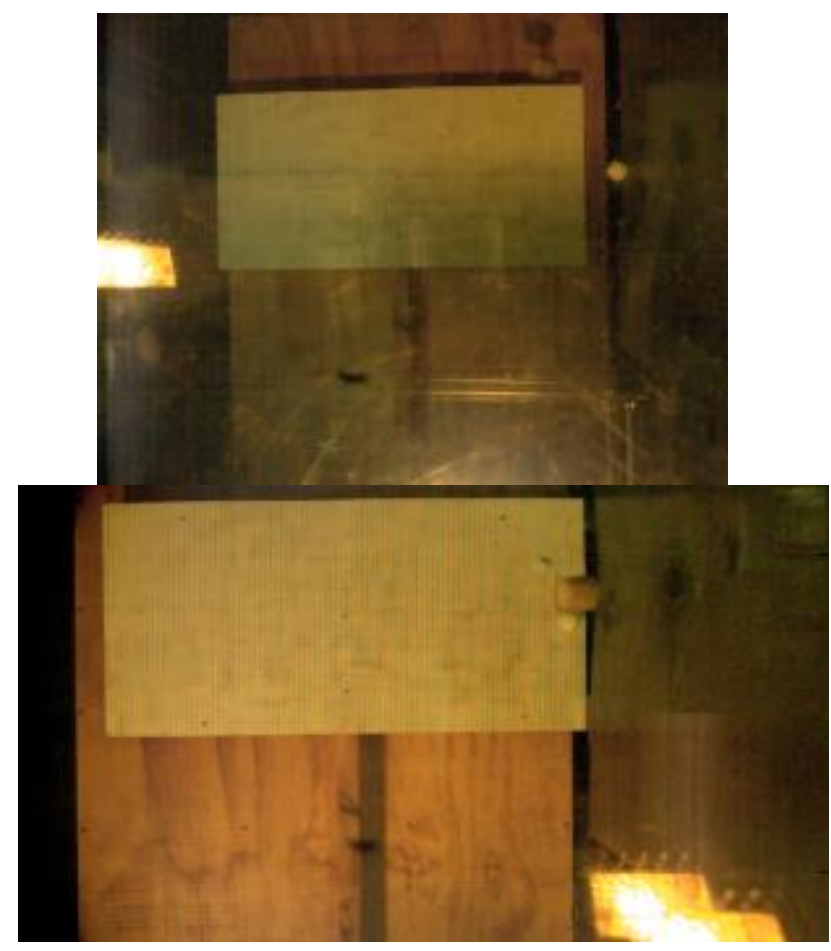

Şekil 14. Yüksek hızlı kamera ile alınan görüntüler(12.5 psi ile atılan, 40 mm çapında,\%1 mikrofiber, \%5 PVA karıșımlı buz topu)

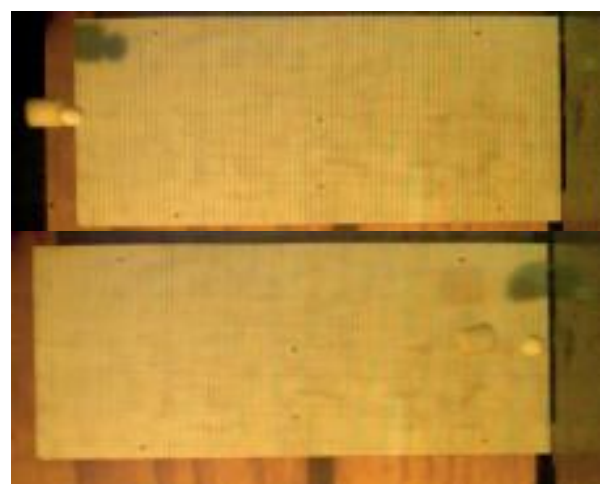

Şekil 15. \%12 PVA karıșımlı buz topunun çarpışmasının yüksek hızlı kameradaki görüntüleri (32 mm çap, 8 psi basinç)

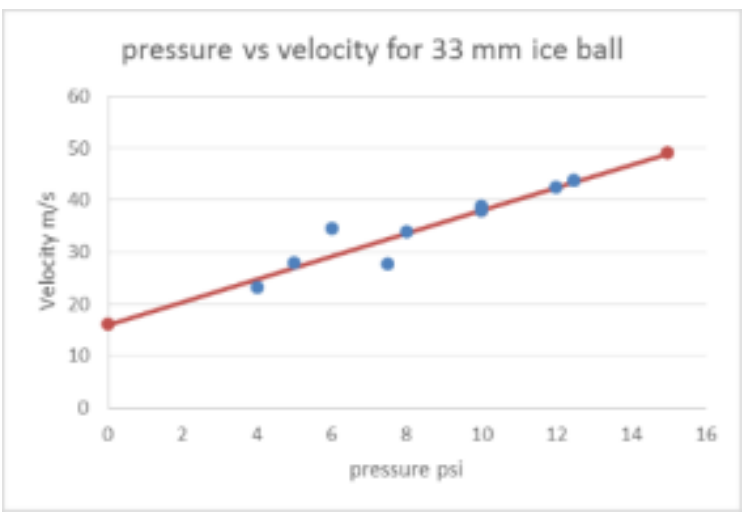

Şekil 16. Gaz tabancı basıncı ve çarpma hızı arasındaki korelasyon(33mm bu topu için)

\section{Tartışma ve Sonuçlar}

Bu çalışmada 22 adet saf buz topu, 29 adet \% 1 mikrofiber ve \% 5 PVA'dan oluşan yapay dolu tanesi ve 17 adet \% 12 PVA'dan oluşan yapay dolu tanesi test edilmiştir. Buz toplarının çapları $25 \mathrm{~mm}, 33 \mathrm{~mm}, 40$ $\mathrm{mm}, 45 \mathrm{~mm}$ ve 50 mm'dir. 5 psi'dan 25 psi'a kadar farklı basınçlar test edilmiştir ve dolayısıyla yaklaşık çarpma hızı $22 \mathrm{~m} / \mathrm{s}$ ve $53 \mathrm{~m} / \mathrm{s}$ arasında değişmiştir. Tablo 2'de test edilen dolu tanelerinin sayısı, içerikleri, boyutu ve uygulanan basınçlar görülebilir.

Tablo 3'te üretilen ve test edilen yapay dolu tanelerinin kalitatif özelliklerini belirtmektedir. Saf buz topların boyutları büyüdükçe uygulanan basınç düşük olsa dahi çarpışma esnasında üç parçaya ayrıldığı gözlemlenmiştir. $\% 5$ PVA ve $\% 1$ mikrofiberden oluşan buz topları 33 mm'den büyük oldukları takdirde çarpışma esnasında kütlesinin bir kısmını kaybetse de daha küçük boyutlu olanlar bütünlüğünü korumuşlardır. Bu çalışmada sadece \% 12 PVA'dan oluşan buz topu tüm boyutlarda ve uygulan basınç değerlerinde bütünlüğünü koruyabilmiştir. Şekil 14 ve Şekil 15 'te sırasıyla \%1 mikrofiber ile birlikte \% 5 PVA içeren ve \% 12 PVA içeren buz toplarının yüksek hızlı kamerayla çekilmiş fotoğrafları görülmektedir. 
Tablo 2 Çalıșmada kullanılan yapay numunelerin boyutu, basincı ve test sayısı

\begin{tabular}{|c|c|c|c|}
\hline Malzeme & $\begin{array}{l}\text { CCap } \\
\text { (mm) }\end{array}$ & $\begin{array}{l}\text { Basinc } \\
\text { (psi) }\end{array}$ & $\begin{array}{l}\text { Test } \\
\text { Sayisi }\end{array}$ \\
\hline \multirow{14}{*}{$\begin{array}{l}\text { PVA fiberli buz } \\
\text { Dolu }\end{array}$} & \multirow[t]{4}{*}{45} & 15 & 1 \\
\hline & & 18 & 4 \\
\hline & & 20 & 5 \\
\hline & & 25 & 2 \\
\hline & 40 & 12.5 & 1 \\
\hline & \multirow[t]{5}{*}{33} & 5 & 1 \\
\hline & & 7.5 & 2 \\
\hline & & 10 & 2 \\
\hline & & 12.5 & 2 \\
\hline & & 15 & 2 \\
\hline & \multirow[t]{4}{*}{25} & 3 & 2 \\
\hline & & 5 & 2 \\
\hline & & 7.5 & 2 \\
\hline & & 10 & 1 \\
\hline \multirow{13}{*}{$\begin{array}{l}\text { PVA Buz Dolu } \\
(12 \%)\end{array}$} & \multirow[t]{5}{*}{50} & 5 & 1 \\
\hline & & 7.5 & 1 \\
\hline & & 10 & 2 \\
\hline & & 12.5 & 1 \\
\hline & & 15 & 1 \\
\hline & 40 & 10 & 1 \\
\hline & \multirow[t]{4}{*}{33} & 4 & 1 \\
\hline & & 8 & 2 \\
\hline & & 12 & 1 \\
\hline & & 15 & 1 \\
\hline & \multirow[t]{3}{*}{25} & 3 & 2 \\
\hline & & 7.5 & 2 \\
\hline & & 10 & 1 \\
\hline \multirow[t]{11}{*}{ Saf Buz Dolu } & \multirow[t]{5}{*}{33} & 3 & 1 \\
\hline & & 5 & 2 \\
\hline & & 10 & 3 \\
\hline & & 12.5 & 3 \\
\hline & & 15 & 4 \\
\hline & \multirow[t]{3}{*}{45} & 3 & 1 \\
\hline & & 18 & 1 \\
\hline & & 20 & 3 \\
\hline & \multirow[t]{3}{*}{50} & 15 & 2 \\
\hline & & 17.5 & 1 \\
\hline & & 20 & 1 \\
\hline
\end{tabular}

Gösterildiği gibi, ilk dolu tanesinin küçük bir parçası koparken ikincisi bütünlüğünü korumaktadır. \% 1 mikrofiber ve \% 5 PVA kullanılmasının avantajı oluşan dolu tanesinin kalitesinin ASTM: F320-10'da tavsiye edildiği gibi yapılan pamuk lifleri kullanılan tanelerden daha fazla olmasıdır. Mevzuat, \% 12 pamuk lifi kullanılmasını şart koşmaktadır[Swift,2013]. Oluşan buz topu buzdan son derece farklı olmaktadır ve pamuk lifleri su içerisinde eşit bir şekilde dağılmadığı için buz topu, her yerinde aynı davranışı gösterememektedir. $\mathrm{Bu}$ yüzden, parçalanmaya karşı dayanıklılığı fazla olmasına rağmen pamuk lifleri etrafinda kalan buz yine de kırılmaktadır.

\% 1 mikrofiber \% 5 PVA'dan olușan buz topunun sahip olduğu daha iyi karışım özelliklerinden dolayı tek biçimlilik sorunu daha azdır. Fakat buz topu yine de çarpışma esnasında bir parçasını kaybetmektedir. \%12 PVA ile olușturulan dolu tanesi 3. Bölüm'de bahsedilen dört kritere de ulaşmaktadır. Bu metotla üretilen dolu taneleri $50 \mathrm{~mm}$ çapa kadar $50 \mathrm{~m} / \mathrm{s}$ hızla çarpmalardan sonra tek parça kalabilmektedir. Bu çarpma hızı $50 \mathrm{~mm}$ çaplı bir dolu tanesinden beklenen $32 \mathrm{~m} / \mathrm{s}$ hızdan çok daha fazladır.
Tablo 3. Çalıșmada kullanılan yapay doluların niteliksel karşılaştırması

\begin{tabular}{|c|c|c|c|c|c|}
\hline Katki & $\begin{array}{l}\text { Çap } \\
\text { mm }\end{array}$ & $\begin{array}{c}\text { Yogunluk } \\
\mathrm{Kg} / \mathrm{m}^{3}\end{array}$ & $\begin{array}{c}\text { Basinc } \\
\text { (Psi) }\end{array}$ & $\begin{array}{l}\text { Carpma } \\
\text { sonrasi } \\
\text { durum }\end{array}$ & $\begin{array}{l}\text { Dolu } \\
\text { hizi } \\
\mathrm{m} / \mathrm{s}\end{array}$ \\
\hline \multirow{2}{*}{$\begin{array}{l}\text { Demine } \\
\text { ralized } \\
\text { (saf) su } \\
\text { ile }\end{array}$} & 33 & 926 & 5 & $\begin{array}{c}\text { Buyuk } \\
\text { Parcalalar } \\
\text { halinde }\end{array}$ & N.A. \\
\hline & 33 & 903 & 15 & $\begin{array}{c}\text { Tamamen } \\
\text { kucuk } \\
\text { parcalar } \\
\text { halinda } \\
\text { dagilma }\end{array}$ & N.A. \\
\hline \multirow{2}{*}{$\begin{array}{l}5 \% \\
\text { PVA, } \\
1 \% \\
\text { micro } \\
\text { fibre } \\
\text { and } \\
94 \% \\
\text { demine } \\
\text { ralized } \\
\text { su }\end{array}$} & 33 & 1015 & 5 & $\begin{array}{c}\text { Neredeyse } \\
\text { saglam } \\
\text { carpma } \\
\text { yerinde } \\
\text { biraz kutle } \\
\text { kaybi } \\
\end{array}$ & 27.8 \\
\hline & 33 & 1011 & 15 & $\begin{array}{c}\text { Carpma } \\
\text { yerinde } \\
\text { buyuk bir } \\
\text { kayip var, } \\
\text { buz parcasi } \\
\text { kirilma var } \\
\text { fiber } \\
\text { sayesinde } \\
\text { tamamen } \\
\text { kopma yok }\end{array}$ & 42.4 \\
\hline \multirow{2}{*}{$\begin{array}{l}12 \% \\
\text { PVA } \\
\text { and } \\
88 \% \\
\text { demine } \\
\text { ralized } \\
\text { su }\end{array}$} & 33 & 935 & 8 & $\begin{array}{c}\text { Sapasaglam } \\
\text { ve geri } \\
\text { sekme } \\
\text { mevcut } \\
\end{array}$ & 34.4 \\
\hline & 33 & 939 & 15 & $\begin{array}{c}\text { Sapasaglam } \\
\text { ve geri } \\
\text { sekme } \\
\text { mevcut }\end{array}$ & 42 \\
\hline
\end{tabular}

Buna ek olarak, üretilen dolu taneleri, doğal dolu tanelerinin karakteristik özelliklerine yakındır. Ayrıca, dolu tanesinin dıș ortama temasıyla bașlayan erime, dolu tanesinin etrafında sudan yapılmış ince bir tabaka olușturarak düșük sürtünme katsayısını korumaktadır. Yoğunlukları da doğal dolu tanelerinin yoğunluk değerinden \% 10'dan daha az uzakta bulunan $1 \mathrm{~g} / \mathrm{cm}^{3}$ olarak bulunmuştur.

Dolu fırtınaları yapılara -özellikle çatılara ve araç panellerine- ciddi zararlar verme potansiyeline sahiptir. Şu an var olan doluya karşı dayanıklılığı değerlendirme metotlarının güvenilirliği, doğal dolu tanelerini temsil edecek bir cismin yokluğundan dolayı fazla değildir. Bu çalışma ile farklı oranlarda mikrofiber ve PVA temelli adhezif madde kullanılarak yapılan keşifler baz alınarak üç farklı metot sunulmuştur. Sonraki aşamada üretilen dolu taneleri, amaç üzerine üretilmiș test malzemeleri kullanılarak yüksek hızlar altında çatı panelleriyle çarpışmalarındaki davranışları değerlendirilecektir. Dolu taneleri $25 \mathrm{~mm}, 33 \mathrm{~mm}, 40 \mathrm{~mm}, 45 \mathrm{~mm}$ ve $50 \mathrm{~mm}$ olmak üzere beş farklı boyuttadır. Dolu tanesi atıcı 22 $\mathrm{m} / \mathrm{s}$ ve $53 \mathrm{~m} / \mathrm{s}$ arasında çarpma hızları yakalanmasını sağlamıştır. Yapılan çalışmadan elde edilen öncelikli sonuçlar şunlardır:

1. Var olan yapay dolu tanesi üretim işlemleri gerçekçi hasar veren dolu tanelerini istikrarlı bir şekilde üretmemektedir. Bu istikrar sağlamak için, üçüncü bölümde bahsedildiği gibi en önemli kriterler yapay dolunun çarpışmadan sonraki bütünlüğünü koruması, yoğunluğu ve darbe etkisini içerir. 
2. Bu çalışma doğal dolu tanelerinin sebep olduğu hasarı temsil edecek yapay dolu tanelerinin yeterli olabilmesi için dört kriter öne sürmüștür. Öncelikle, dolu tanesinin çoğunluğu buzdan oluşmalıdır. İkinci olarak, dolu tanesinin nitelikleri her yerinde aynı olmalıdır. Üçüncü olarak, yapay dolu tanelerinde gerçek dolu tanelerinde gözlemlenen yüzey erimesi gerçekleşmelidir. Sonuncu ve en önemli kriter ise, istenen limit hızda çapan dolu taneleri bütünlüklerini korumalıdır.

3. Makale saf buz, \% 1 mikrofiber + \% 5 PVA katkılı ve \% 12 PVA katkılı olmak üzere üç ayrı dolu tanesi üretim metodunu tarif etmiştir. Buz toplarına mikrofiber ve PVA eklenmesiyle çekme dayanımları artmıștır. Bu şekilde üretilen buz topları yüzey özellikleri ve yoğunlukları, doğal dolu tanelerinde olan değerlere mümkün olduğunca yakın olmaktadır. Öne sürülen metotla üretilen \% 12 PVA içeren, çapları 50 mm'ye kadar olan dolu taneleri $50 \mathrm{~m} / \mathrm{s}$ hızın altında çarpma hızı altında dahi (ki bu hız, benzer boyutlu doğal dolu tanesi için tahminen $32 \mathrm{~m} / \mathrm{s}$ olan çarpma hızı değerinden çok daha fazladır) bütünlüklerini koruyabilmektedir.

\section{Conflict of Interest / Çıkar Çatışması}

Yazarlar tarafından herhangi bir çıkar çatışması beyan edilmemiştir.

No conflict of interest was declared by the authors

\section{Kaynaklar}

American Society for Testing and Materials, (2009), ASTM E822 Standard Practice for Determining.

ANSI, (2011), Test Standard for Impact Resistance Testing of Rigid Roofing Materials by Impacting with Freezer Ice Ball ANSI FM 4473. Norwood, MA, U.S.A.

ASTM:D3746-85, (2008), Standard Test Method for Impact Resistance of Bitumious Roofing System. West Conshohocken, PA, United States: ASTM International.

Australian Building Codes Board, (2010), An Investigation of Possible Building Code of Australia (BCA).

Basara, Jeffrey B.; Cheresnick, Daniel R.; Mitchell, DeWayne and G. Illston, Bradley, (2007), An Analysis of Severe Hail Swaths in the Southern Plains of the United States.

Bengtsson, J., Hargreaves, R. and Page, I.C., (2007), Assessment of The Need to Adapt Buildings in New Zealand to the Impacts of Climate Change, Wellington.
Brimelow, J.C.; Reuter, G.W. and Poolman, E.P. (2002a): Modeling maximum hail size in Alberta thunderstorms. Wea. Forecasting, 17, 1048-1062.

Bureau of Meteorology, (2007), Severe Thunderstorms: Facts, Warnings and Protection.

Chang, D.C. and Khetan, R.P., (1984), Surface Damage of Steel, Aluminum, and Chopped-Fiber Composite Panels Due to Projectile Impact. Journal of Reinforced Plastics and Composites, 3(3), 193203.

Crenshaw, B.V. and Koontz, J.D., (2002), Hail : Sizing It Up! Western Roofing Magazine, 2-7.

Dunlop, S., (2008), Oxford Dictionary of Weather 2nd Ed., New York: Oxford University Press.

Emergency Management Australia, (2003), Hazards, Disasters and Your Community (PDF). Canberra, Australia: Emergency Management Australia.

Engelbert, P., (1997), The Complete Weather Resource Volume 2: Weather Phenomena, Detroit: UXL.

Farley, R.D.; Wu, T.; Orville, H.D. and Hjelmfelt M.R., (2004), Numerical simulation of hail formation in the 28 June 1989 Bismarck thunderstorm: Part I. Studies related to hail production. Atmos. Res. Vol. 71, 51-79.

Fleming, H.G.; Skarajew, M.; Szalla, (1997), J.A.G. A Laboratoy Dent Test for Outer Panel Steels.

Flüeler, P.; Stucki, M.; Guastala, F. and Egli, T., (2008), Hail Impact Resistance of Building Materials Testing, Evaluation and Classification. 11DBMC International Conference on Durability of Building Materials and Components ISTANBUL. Turkey: Istanbul Technical University, Istanbul, Turkey.

Giammanco, I. M. and Brown, T. M., (2014), Observations of Hailstone Characteristics in Multicell and Supercell Thunderstorms. Insurance Institute for Business and Home Safety.

Hile, K., (2009), The Handy Weather Answer Book, Visible Ink Press.

Hurriyet Gazetesi, (2017), Son afetlerin maliyeeti 300 milyon TL, www.hurriyet.com, Basım Tarihi: 03/08/2017

Insurance Institute for Business and Home Safety (IBHS), (2013), From Concept to Reality: The FirstEver Indoor Hailstorm,

Johnson, T.E. and Schaffnit, W.O., (1973), Dent Resistance of Cold-Rolled Low-Carbon Steel Sheet. SAE Technical Paper, 730528.

Juntikka, R. and Olsson, R., (2009), Experimental and Modelling Study of Hail Impact on Composite Plates. ICCM 17, Edinburgh.

Kim, H. and Kedward, K.T., (1999), Experimental Measurement and Numerical Prediction of Hail Ice Impact Damage on Composite Panels. ICCM 12 Conference, Paris. 
Kim, H., Welch, D.A. and Kedward, K.T., 2003, Experimental Investigation of High Velocity Ice Impacts on Woven Carbon/Epoxy Composite Panels. Composites Part a: Applied Science and Manufacturing, 34, 25-41.

Knight, C.A. and Knight, N.C., (1976), Hail Embryo Studies. International Conference on Cloud Physics, Boulder, Colorado. Boston, Mass. American Meteorological Society. United States.

Krauss, T.W. and Reuter, G.W. (2002b): Operational forecasts of maximum hailstone diameter in Mendoza, Argentina, J. Wea. Mod., 34, 8-17.

Laurie, J.A.P., (1960), Hail and Its Effects on Buildings, Research Report 176, NBRI, Pretoria, South Africa.

Lavoie, M.A.; Nejad E.M. and Gakwaya, A., (2011), Development of an Efficient Numerical Model for Hail Impact Simulation Based on Experimental Data Obtained from Pressure Sensitive Film. Mechanics Research Communications, 38, 72-76.

Leslie, L.M., Leplastrier, M. and Buckley, B.W., (2008), Estimating Future Trends in Severe Hail Storms over the Sydney Basin: A Climate Modelling Study. Atmos. Res., 87, 37-51.

Lru, H., (1979), Fracture Toughness of Fresh-Water Ice.

Maguire, R., (2014), Experimental Determination of the Effects of Hail Impact on Steel Building Envelopes. Civil, Mining and Environmental Engineering, M.B.Eng. Thesis.

Mcccormick, M.; Fekete, J.; Meuleman, D. and Shi, M., (1998), Effect of Steel Strengthening Mechanisms on Dent Resistance of Automotive Body Panels. SAE Technical Paper.

Michaud, A.B.; Dore, J.E.; Leslie, D.; Lyons, W.B.; Sands, D.C. and Priscu, J.C., (2014), Biological Ice Nucleation Initiates Hailstone Formation. Journal of Geophysical Research: Atmospheres, 119, 12,186-12,197.

Moore, D.M. and Wilson, A., (1978), Photovoltaic Solar Panel Resistance to Simulated Hail, Department of Energy.

Nelson S. P., (1983), The influence of storm flow structure on hail growth. J. Atmos. Sci.,40, 19651983.

Niemeier, A. and Reynolds, C.E.B., (1978), Hailstone Response of Body Panels Real and Simulated Bernard.

Nomura, S.; Yutori, Y.; Iwaya, J.; Miyahara, M. and Kokubo, I.A., (1984), Study of the Dynamic Dent Resistance. 13th. Biennial Congress International Deep Drawing Research Group-Efficiency in Sheet Mental Forming.

Oard, M., (2015), The New Weather Book, New Leaf Publishing Group, Incorporated.
Olsson, R.; Donadon, M.V. and Falzon, B.G., (2006), Delamination Threshold Load for Dynamic Impact on Plates. International Journal of Solids and Structures Vol. 43, 3124-3141.

Paterson, D. and Sankaran, R., (1994), Hail Impact on Building Envelopes. Journal of Wind Engineering and Industrial Aerodynamics Vol. 53, 229-246.

Pflaum, (1980), Courtesy of the American Meteorological Society.

Render P. and Pan, H., (1995), Experimental Studies into Hail Impact Characteristics. Journal of Propulsion and Power Vol. 11, 1224-1230.

Rhymer, J.D., (2012), Force Criterion Prediction of Damage for Carbon/Epoxy Composite Panels Impacted by High Velocity Ice. University of California.

Sain, T. and Narasimhan, R., (2011), Constitutive Modeling of Ice in The High Strain Rate Regime. International Journal of Solids and Structures, 48, 817-827.

Shi, M. F.; Brindza, J.; Michel, P.; Bucklin, P.; Belanger, P. and Prencipe, J., (1997), Static and Dynamic Dent Resistance Performance of Automotive Steel Body Panels. SAE Technical Paper.

Steingold, M.; Walker, G., May (1999), Sydney Hailstorm 14 April 1999: Impact on Insurance and Reinsurance (PDF). Aon Re Australia Limited. Archived from The Original (PDF) on 2 September 2007. Retrieved 8 September 2007.

Sun, J., et al., (2015), Contact forces generated by hailstone impact. International Journal of Impact Engineering Vol. 84: 145-158.

Swift, J. M., (2013), Simulated Hail Ice Mechanical Properties and Failure Mechanism at Quasi-Static Strain Rates. Master of Science in Aeronautics and Astronautics, University of Washington.

Tang, Z., et al., (2017), "Numerical and experimental investigation on hail impact on composite panels." International Journal of Impact Engineering Vol. 105: 102-108.

Tippmann, J.D., (2011), Development of a Strain Rate Sensitive Ice Material Model for Hail Ice Impact Simulation. M.S., UC San Diego, University of California, San Diego.

Tobias, H., Ilia, V.R. and Cameron, D.T., (2014), Investigation of The Impact Behaviour of Ice Particles. 6th AIAA Atmospheric and Space Environments Conference. American Institute of Aeronautics and Astronautics.

Türkiye Ulusal Afet Arşivi (TUAA) verileri, 1970-2012.

USS . Hail Damage on Coated Sheet Steel Roofing., (2005), U. S. Steel Technical Bulletin-Construction.

Uz, M. E., Teh L. and Maguire J., (2014), Developing Australia's first hail-proof roofing profiles. Research Case Study. Open Days's Poster, SBRC. 
Veldhuizen, B.V.; Kranendonk, W.; Ruifrok, R. and BV, H. C., (1995), The Relation Between the Curvature of Horizontal Automotive Panels, The Panel Stiffness.

Yılmaz, K.F. (2008), Antalya'nın Günlük Yağıș Özellikleri ve Şiddetli Yağışların Doğal Afetler Üzerine Etkisi. Sosyal Bilimler Dergisi / Sayı 1. 